Review Article

\title{
A REVIEW FROM HISTORICAL TO CURRENT-CELASTRUS PANICULATUS
}

\author{
GANESH N. SHARMA ${ }^{1}$, HARJINDER KAUR ${ }^{1 *}$, BIRENDRA SHRIVASTAVA ${ }^{2}$, SATISH CHANDER ARORA $^{3}$
}

${ }^{1,2}$ School of Pharmaceutical Sciences, Jaipur National University, Jaipur, ${ }^{3}$ RKSD College of Pharmacy, Kaithal Email: ysdverma@gmail.com

Received: 27 May 2020, Revised and Accepted: 30 Jun 2020

\begin{abstract}
Celastrus paniculatus is commonly known as "Malkangani”, widely distributed in the Maldives, Australia, China, Cambodia, Malaysia, Taiwan, Nepal, Thailand as well as in the Pacific Islands and all over India mainly Maharashtra, Orissa and Andaman and Nicobar group of Islands on an altitude of $1800 \mathrm{~m}$. It climbs up to over $10 \mathrm{~m}$. The leaves are ovate or elliptic in shape with dentate margin. Seeds are ellipsoid or ovoid, yellowish-brown in color and grow inside the capsules. Celastrus paniculatus (Malkangni) is used in Ayurveda as a nervine tonic, tranquilizer and diuretic and in rheumatism, gout, leprosy and asthma. Different Parts of Celastrus paniculatus after extraction and fractionation give different active constituents such as sesquiterpene esters-malkanguinol, malkangunin, sesquiterpene alkaloids-celapanin, celapanigin, alkaloids-celastrine, paniculatine, fatty acids-oleic acid, palmittic acid, linoleic acid and stearic acid, crystalline substance tetracasanol and sterol. Different pharmacological activities are anti-rheumatic, anti-fungal, nootropic activity, antimalarial activity, anti spermatogenic effect, anti-anxiety and anti-atherosclerotic effect. In the present review, our target is to search, bring together and compile the data of Celastrus paniculatus, which have less side effects and very valuable for the treatment of rheumatism. Related information is procured from various scientific publications using online, seek out engines such as Google scholar, Pubmed and Science Direct. A total of 200 articles was reviewed out of which 55 articles are selected to review for the description of the plant, parts used, chemical constituents, traditional uses and for reported activities.
\end{abstract}

Keywords: Celastrus, Rheumatism, Celapanin, Leaves, Malkangunin

(C) 2020 The Authors. Published by Innovare Academic Sciences Pvt Ltd. This is an open access article under the CC BY license (http://creativecommons.org/licenses/by/4.0/) DOI: http://dx.doi.org/10.22159/ijpps.2020v12i8.38470. Journal homepage: https://innovareacademics.in/journals/index.php/ijpps.

\section{INTRODUCTION}

Herbal medicinal plants are used for the treatment of various diseases and it will not be an overstatement that use of these medicinal plants is as old as the mankind [1]. In USA, Australia and Canada, Market of herbal medicine has a turnover of about US\$30 billion in 2000 which was increased up to $5-15 \%$ by the turn of the century [2]. Worldwide annual market of herbal medicine has reached to $\$ 60$ billion. The industrialized societies have been discovered to the extraction of active constituents and the development of several drugs and chemotherapeutic from these plants as well as from traditionally used rural herbal remedies. Celastrus paniculatus is one of the plants which has a rich source of therapeutically and medicinally potential active constituents.

\section{Search strategy used}

The review of literature related to the present study was done in the period from March 2018 to till date. The search terms used were 'Celastrus paniculatus', 'Malkangani', 'Biological activities of Celastrus paniculatus', 'Traditional uses of malkangni', 'Description of jyotishmati'. The present search and study were done by referring various textbooks, journals containing peer review and research papers. The electronic databases used were Science Direct, PubMed, which provides free access to Medline, Google. Only published articles with different languages from 1970 to till date were used for the more elaborated study to make the latest review article on Celastrus paniculatus. Reference lists of articles were also cross-checked.

Description of Celastrus paniculatus

Binomial name

Celastrus paniculatus Wild.

Synonym

Celastrus dependens Wall.

Common Indian Name

\begin{tabular}{ll}
\hline Hindi & Malkagni, Malkakni \\
Gujarati & Black-oil tree, Climbing staff tree \\
Sanskrit & Malkangani, Velo \\
Bengali & Jyotishmati, Svarnalota \\
Marathi & Jyotishmati, Svarnalota \\
Malayalam & Polulavam \\
\hline
\end{tabular}

Scientific Classification

\begin{tabular}{ll}
\hline Kingdom & Plantae \\
Sub kingdom & Angiosperms \\
Class & Magnoliopsida \\
Division & Tracheophytes \\
Order & Celastrales \\
Family & Celastraceae \\
Genus & Celastrus \\
Species & C. paniculatus \\
\hline
\end{tabular}




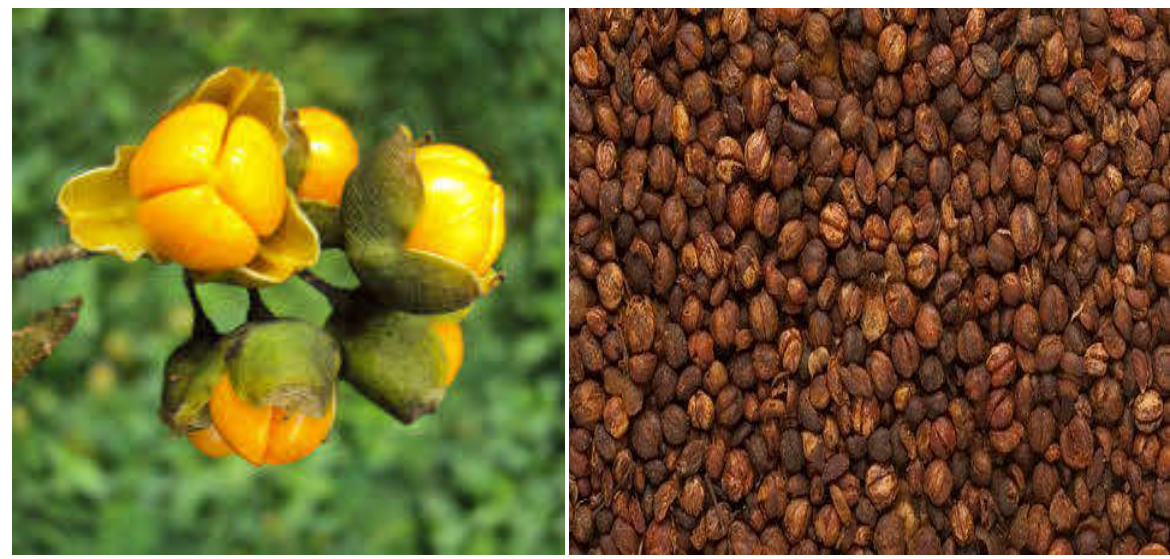

Seeds of Celastrus paniculatus (Source-Wikepedia and India mart)

\section{Parts used}

Seeds, leaves, root and stem

Family

Celastraceae

\section{Genus Celastrus}

Celastrus is a genus of woody, climbing shrub distributed over China, Japan, Australia, Tropical North America and Pacific Islands. There are seven species of Celastrus in India one of which is Celastrus serratus Hoechst present in Indian Botanical Garden Howrah. It is commonly known as Bittersweet or Staff tree. It is grown on almost each type of soil and situation [3].

\section{Celastraceae}

Celastraceae family is found in tropical and subtropical regions of the world, including North Africa, South America and many parts of East Asia, mainly in China $[4,5]$. Celastraceae is a family having 96 genera and 1350 species of herbs, wine and small tree. Celastraceae has five subfamilies Celastroideae, Hippocrateoideae, Parnassioideae, Salacioideae and Stackhousioideae. Some of the genera of Celastraceae are Celastrus, Kokoona, Salacia, Gymnosporia and Euonymus. Leaves are simple with an alternate pattern. Flowers are hermaphrodite and cymene. Seeds have fleshy endosperm with large embryo and dicotyledon. In the last thirty years, a number of secondary metabolites are isolated from Celastraceae, of which main constituents are sesquiterpenoids, phenyl alkyl amine and flavonoids [6]

\section{Geographical distribution}

Celastrus paniculatus grow in different variety of climates and environments. It is mainly found in India, especially in Punjab, Kashmir and hilly area at an altitude of $3000 \mathrm{~m}$ and abundantly found in Simlipal Biosphere Reserve Forest, Karlapat Sanctuary and Niyamgiri hills [7]. It is also widely distributed in Sri Lanka, Maldives, Philippines, Australia, China, Cambodia, Vietnam, Malaysia, Taiwan, Nepal, Thailand as well as in the Pacific Islands.

\section{Organoleptic evaluation}

\section{Leaves}

\section{Color: Green}

Shape: Oval or elliptic

Texture: Leathery and smooth

Arrangement: Alternate

Margin: Toothed

Apex: Acute, acuminate

Base: Obtuse or rounded

\section{Bark}

Color: Outer bark is pale or reddish-brown while the inner bark is light yellow in color

Surface: Rough and cracked

\section{Flower}

Color: Greenish White or yellowish-green, hermaphrodite, pubescent Fruit

Fruits are globose, yellow in color with three to six seeds Seed

Color: Reddish brown

Shape: Ellipsoid in shape enclosed in orange, red fleshy aril and grows inside the fruits

Odor: Unpleasant

Taste: Bitter

Chemical constituents

Seeds

Sesquiterpene alkaloids

Celapanin, Celapagine, Celapanigine

\section{Monounsaturated and polyunsaturated fats}

\section{Sesquiterpene ester}

$1 \alpha, 6 \beta, 8 \beta$-triacetoxy-9 $\beta$-benzoyloxydihydro beta-agarofuran along with the some known compounds which are $1 \alpha, 6 \beta, 8 \alpha$-triacetoxy$9 \alpha$-benzoyloxydihydro-beta agarofuran angulatueoid $\mathrm{C}$, and $1 \alpha, 6 \beta$ $8 \beta, 14$-tetra acetoxy- $9 \alpha$-benzoyloxy dihydro beta-agarofuran from the carbon tetrachloride-soluble fraction of Celastrus paniculatus methanolic seed extract [8].

\section{Triterpenoids}

Pristimerin [9]

\section{Fatty acids}

Palmittic, Oleic, Linoleic and Linolenic acid.

$80 \%$ of the methanolic extract of seed oil contain Malkanguinol, Malkangunin, Paniculatadiol.

\section{Polyalcohol esters}

Malkagunuin, Polyalcohol A, B, C and D [10,11]

\section{Sterols}

Vitamin C, minerals, carbohydrates and proteins are also found in the seeds $[12,13]$. 
Stem

Alkaloid such as Wifornine F, Paniculatine A and B are isolated from the stem [14].

\section{Root bark}

Petroleum ether extract of the root bark of Celastrus paniculatus shows alkaloids such as n-triacontanol and pristimerin, benzoic acid, uncharacterized quinine and golden-yellow oil. Zeylaseral, zeylasterone, celastrol found as qunione, methide and phenolic triterpenoids in outer root bark [15].

Ethanolic extract of Celastrus paniculatus shows the presence of tannins.

\section{Leaves}

Leaves contain an alkaloid, a glycoside and a coloring matter. It contains dulcitol.

\section{Traditional uses}

Plants are used in the treatment of various ailments from the prehistoric times. Ayurveda is the ancient traditional system of medicine, which includes a large number of medicinal plants for the treatment of diseases. Celastrus paniculatus is one of the plants which are used in Ayurveda as a nervine tonic, tranquilizer and a diuretic, in treatment of rheumatism, gout, leprosy and asthma [16, 17]. Charka Samitha and Sushruta Samitha describe its roots uses in headache, depression, as laxative, purgative and in urinary disorders, skin problems and in neurologic disorders [18]. In Unani and Siddha medicines, it is used for gout, lumbago and to relieve fatigue [19]. It is used in Chinese medicine to treat fever, joint pain edema and rheumatoid arthritis [20,21]. Powdered root bark is used in the treatment of malaria [22]. In an Indian traditional system of medicine Celastrus paniculatus is used as emetic, aphrodisiac, in treatment of anorexia, constipation, cough and skin infections [23].

\section{Ethnobotanical study}

In traditional Himalayan medicines Celastrus paniculatus is used to reduce the swelling of the veins of the anus and rectum, which causes discomfort and bleeding, in treatment of rheumatism, diarrhea and leprosy [24]. Crushed roots are used for pneumonia in folk medicines [25]. A Gond tribe of Uttar Pradesh uses the powdered root in the treatment of cancer [26]. In the Chendwara and Betul district of Madhya Pradesh powder of the root and decoction of seeds of Celastrus paniculatus used to treat rheumatism [27, 28]. The oil of seeds of Celastrus paniculatus is used by herbal therapist for hair growth and to make the hair silky [29]. Tribes of Purandhar [30] and tribes of Jalgaon and Nandurbar districts of Maharashtra [31, 32] use the seed oil on joints for the treatment of rheumatic pain. They also use the oil orally and topically for the treatment of paralysis in the morning and evening [33]. In the Mayurbhanj district of Odisha it is used for joint diseases, gout and rheumatism. Codified literature of Himachal Pradesh shows its uses as cardiotonic, carminative, anthelmintic and in the treatment of skin infections.

\section{Reported activities of Celastrus paniculatus}

\section{Tranquilizing effect}

Karanth et al., 1980 evaluated seed oil of Celastrus paniculatus at the dose of $200 \mathrm{mg} / \mathrm{kg}$ for its tranquilizing effect on mice [34]. The study revealed that it decreased the spontaneous motor activity, amphetamine-induced hyperactivity and consumption of oxygen in mice. It increased the effect of hexobarbitone and produce hypothermia in mice.

\section{Antimalarial activity}

Celastrus paniculatus extract from the root bark and stem was evaluated by Pavanand et al., 1989 for antimalarial activity against Plasmodium falciparum by in vitro method. In comparison to stem, root bark showed better antimalarial activity [9]. Further a quinonoid triterpene was isolated from a chloroform extract for in vitro antimalarial activity, but this was less active than conventional antimalarial drug tested.

\section{Antifertility activity}

Antifertility effect was studied on the liver and testis of rats by using the oily extract of seeds of Celastrus paniculatus by Bidwai et al., 1990. Intraperitoneal treatment of $0.2 \mathrm{ml}$ of Celastrus paniculatus oil for $30 \mathrm{~d}$ showed vacuolization, cell depletion and arrest of spermatogenesis [35].

Singh and co-workers, 2018 reported antifertility efficacy of ethanol extract of Celastrus paniculatus seed in male rats [36]. When a dose of $250 \mathrm{mg} / \mathrm{kg}$ was given orally to the rats for $45 \mathrm{~d}$, the reproductive organ weight, sperm count and motility were decreased. Biochemical estimation showed that testicular enzymes lactate dehydrogenase and gamma glutamyl transpeptidase activity was increased while sorbitol dehyrogenase activity was decreased.

\section{Anti-inflammatory activity}

Inflammation is a defense mechanism of a tissue reaction to infection, injury or a foreign substance. Ahmad and his colleagues, 1994 used the methanolic extract of the flowers of Celastrus paniculatus for anti-inflammatory activity by using hot water tail immersion test in mice and carrageenan-induced edema in rats [37]. Results revealed that flowers have both analgesic and antiinflammatory activity.

Alcoholic and methanolic extracts of Celastrus paniculatus seeds were used by Parimala et al., 2009 for evaluating their antiinflammatory activity [38]. Screening was done on rats of 150-250 gm by a carrageenan paw edema method using plethysmograph. The standard drug used was diclofenac sodium. Mean increase in the paw volume and percentage inhibition of inflammation revealed that Celastrus paniculatus seeds possess good anti-inflammatory activity.

Kulkarni and his coworkers, 2015 prepared the absolute alcoholic extract of seeds of Celastrus paniculatus and gave it to $120-150 \mathrm{~g}$ male Wistar rats [39]. Experimental evaluation showed a significant anti-inflammatory effect of the alcoholic extract of Celastrus paniculatus seeds which may be related to inhibition of prostaglandin synthesis and IL-1 $\beta$.

\section{Cognitive enhancement activity}

Gattu et al., 1997 studied that chronic administration of Celastrus paniculatus seed oil when given orally reversed the declension of spatial memory produced by a central musurinic receptor blockade in rats [40]. While the acute administration did not significantly reverse this effect.

The same effects were evaluated by Bhagya et al., 2016 using Celastrus paniculatus oil in Wistar rats [41]. They recorded the behavior of rats in the open field and then behavioral test was conducted in dimmed room, after that anxiety test was studied in elevated plus maze, partially baited radial arm maze and t-maze rewarded alteration task methods. Observations made by them showed that chronic dose of Celastrus paniculatus seeds oil exhibit neuroprotective effects on chronic stress induced cognitive impairment.

\section{Nootropic activity}

Gupta and Kumar, 2002 investigated aqueous, methanolic, chloroform and petroleum ether extracts of Celastrus paniculatus seeds at the dose of $200 \mathrm{mg} / \mathrm{kg}$ for nootropic effect in male Wistar rats by using a shuttle box, step through, step down and elevated plus maze paradigms [42]. After experimentation, it was observed that only aqueous extract improved the memory of rats.

Celastrus paniculatus is also reported as a nootropic drug by Bhanumathi and coworker, 2010. Methods used for nootropic activity were elevated plus maze and passive avoidance test [43]. In elevated plus maze method, they gave the aqueous extract of seed of Celastrus paniculatus by using doses of 350 and $1050 \mathrm{mg} / \mathrm{kg}$ and in passive avoidance test they gave the doses of 500 and $1500 \mathrm{mg} / \mathrm{kg}$ for the mice. The standard drug used was piracetam with a dose of 100 $\mathrm{mg} / \mathrm{kg}$ and sodium nitrite was used to induce amnesia. Results obtained showed that the Celastrus paniculatus seed extract enhance the memory power by inhibiting acetyl cholinesterase enzyme, and thereby increase the acetylcholine level in the brain. 
Raut and Colleagues, 2015 evaluated the same activity using Celastrus paniculatus seed oil and an equal amount of ghee at a dose of $200 \mathrm{mg} / \mathrm{kg} /$ day orally in mice [44]. Evaluation demonstrated that Celastrus paniculatus oil with ghee has a potential drug in the treatment of dementia.

Similar activity was evaluated by Jakka, 2016 by using whole plant of methanolic extract of Celastrus paniculatus using elevated plus, morris water maze on scopolamine and aluminum-induced amnesia and estimation of acetylcholinesterase enzyme activity [45]. After experimentation Jakka observed that Celastrus paniculatus extract significantly improved learning and memory power of rats as transfer latency in elevated plus maze and escape latency in the morris water maze model showed a declined. Further acetyl cholinesterase enzyme concentration in the brain was decreased and $\%$ of inhibition of acetylcholine activity in rat brain increased which shows the nootropic effect of Celastrus paniculatus.

\section{Antioxidant activity}

Gupta and Kumar, 2002 evaluated cognitive property of the seeds of Celastrus paniculatus in rats by using petroleum ether, chloroform, methanol and aqueous extracts and founded that only the aqueous extract show improvement in learning and memory power. As we know that memory loss is associated with oxidative stress they further tested the aqueous extract for antioxidant activity by using doses of 100,200 and $300 \mathrm{mg} / \mathrm{kg}$, out of that only 200 and $300 \mathrm{mg}$ doses lead to a significant decrease in malanodialdehyde and the increase in glutathione and catalase level in the brain. Thus gave confirmation of memory-enhancing and antioxidant effect

Alama and Haque, 2011 studied the antioxidant activity of seeds of Celastrus paniculatus by 2,2-diphenyl-1-picrylhydrazyl (DPPH) free radical scavenging method [46]. They done the extraction of seed with methanol and further fractioned it with water, chloroform and ethanol. The evaluation showed that ethanolic fraction shows highest activity in DPPH free radical scavenging activity and also inhibit activity of authentic proxy nitrite and total reactive oxygen species. The chloroform extract showed a moderate and aqueous extract had no activity in DPPH method.

In vitro antioxidant activity of ethanolic extract of Celastrus paniculatus leaves was evaluated by Sharma and Shrivastava, 2013 by reducing power assay. In this method, there was an increase in absorbance of the reaction mixture, which may be due to the active constituents present in the Celastrus paniculatus leaves extract and total phenolic content present was $125.6 \mathrm{mg} / \mathrm{gm}$ equivalent to gallic acid in $1 \mathrm{mg} / \mathrm{ml}$ of the extract [47].

Celastrus paniculatus fruit seed oil showed good antioxidant activity when performed by the DPPH method by Ramadan, 2019.

\section{Antibacterial activity}

Harish et al., 2007 reported that ethanolic extract higher than $100 \mu \mathrm{g}$ and the isolated, purified constituent celapanin higher than $50 \mu \mathrm{g}$ per $100 \mu$ l of Celastrus paniculatus leaves exhibited a better zone of inhibition when screened by agar well diffusion method against Staphylococcus aureus (gram-positive bacteria). Against Pseudomonas aeruginosa and Klebsiella pneumonia (gram-negative bacteria) ethanolic extract and celapanin showed reasonable activity compared to the standard drug Ciprofloxacin $(50 \mu \mathrm{g} / 100 \mu \mathrm{l})$. The dissimilarity in the activity may be due to differences in the cell wall because in gram-positive bacteria, the cell wall is a single layer while in gram-negative bacteria, it is multi-layered [48].

\section{Hypolipidemic effect}

Hypolipidemic effect of Celastrus paniculatus seeds was evaluated by Patil and coworkers, 2010 by extracting seeds with methanol and then testing the dose of $65 \mathrm{mg} / \mathrm{kg}$ in experimentally induced hyper cholesterolemia rats orally. Results showed that Celastrus paniculatus decreased the total plasma cholesterol, triglyceride and Low-density lipoprotein (LDL) level comparable to standard hypo cholestrolemic drug and induced hyper cholestrolemic rats. There was an increase in High-density lipoprotein (HDL) cholesterol level, lipoprotein lipase activity and less deposit of cholesterol in aorta of rats that were fed with seed extract.

\section{Antifungal activity}

Singh et al., 2010 investigated the antifungal activity of methanolic extract of roots and aerial parts of three plants, namely Acorus calamus, Tinospora cordifolia and Celastrus paniculatus against Curvularia lunata, Fusarium, Bipaloris and Helminthosporium species [49]. They used the doses of 1000, 2000, 3000, 4000 and $5000 \mu \mathrm{g} / \mathrm{ml}$. The result showed that Celastrus paniculatus at the dose of $5000 \mu \mathrm{g} / \mathrm{ml}$ had better activity against Celastrus lunate and Fusarium.

Antifungal potential of Celastrus paniculatus mother plant leaves and in vitro raised clones was also investigated by using chloroform and methanolic extracts against Phytophthora capsici and Rhizoctonia solani by Sasidharan and Elyas, 2019 [50]. Growth of fungi and its percentage was checked on the dextrose agar medium. The brine shrimp lethality assay was done to check the cytotoxicity of extracts of Celastrus paniculatus leaves. After experimentation, it was clear that the methanolic extract of both mother plant and in vitro raised clones showed 100 percent of inhibition of Phytophthora capsici while chloroform extract of mother plant had very less activity and in vitro propagated plants showed 40 percent of inhibition and against solani, the methanolic extract showed maximum activity and chloroform extract showed $77.77 \%$ and $86.66 \%$ respectively.

\section{Neuromodulating effects}

Sumathi et al., 2013 investigated the alcoholic seed extract of Celastrus paniculatus (ASECP) to prevent aluminium induced neurotoxicity in the cerebral cortex and the cerebellum of the rat brain. They gave the aluminium chloride at a dose of $4.2 \mathrm{mg} / \mathrm{kg} /$ day i. $\mathrm{p}$. for $4 \mathrm{w}$ to male albino rat. Experimental rats were given two different doses of 200 and 400 $\mathrm{mg} / \mathrm{kg} /$ day orally of Celastrus paniculatus seed extract $1 \mathrm{hr}$ prior to the aluminium chloride administration for $4 \mathrm{w}$. At the end, results showed that aluminium administration significantly decreased the level of glutathione and the activities of superoxide dismustase, glutathione peroxidase, $\mathrm{Na}^{+} / \mathrm{K}^{+}$ATPase, $\mathrm{Ca}^{2+}$ ATPase and $\mathrm{Mg}^{2+}$ ATPase and increased the activities of alkaline phosphatase, acid phophatase, alanine transaminase and aspartate aminotransferase in all the brain regions when compared with control rats. Aluminium induction also caused histopathological changes in the cerebral cortex and cerebellum of rat brain, which was reverted by pretreatment with ASECP. The result clearly indicates the potential of the seed extract of Celastrus paniculatus prevents the damage inflicted by aluminum on rat brain regions [51]

\section{Iron chelating activity}

Nakhva and colleagues, 2015 evaluated that the methanolic extract of seeds of Celastrus paniculatus for in vitro iron-chelating activity by using various reagents like ferrous sulphate, potassium thiocynate and desferrioxamine [52]. Further, in vivo activity was also done that decreased the serum iron level in the test group as compared to the disease treated control group. SGPT, SGOT and Creatinine levels were reduced as compared to iron overloaded rats. So the methanolic seed extract can be used to treat thalassemia and hemochromatosis.

\section{Anti-arthritic activity}

Kothavade et al., 2015 used the petroleum ether extract of Celastrus paniculatus seeds to study the anti-arthritic effect in adjuvantinduced arthritis in rats [53]. After evaluation of arthritis score, paw volume, body weight, climbing ability and thymus and spleen index, it was clear that Celastrus paniculatus seed extract alleviated all these parameters that were due to suppression of overproduction of inflammatory cytokines, cellular enzymes. It also restored the decreased level of superoxide dismustase, catalase and glutathione. The results suggested that the anti-arthritic effect may be due to cytokine regulation, immune-suppressive effects, and bone protective activities. In vitro anti-arthritic activity of Celastrus paniculatus was also studied by Thangaraj, 2016 [54].

\section{Antidepressant-like activity}

Behavioral and biochemical evidences for antidepressant-like activity was evaluated by Valecha and Dhingra, 2016 by using the 
seed oil of Celastrus paniculatus [55]. Seed oil at the dose of 50, 100 and $200 \mathrm{mg} / \mathrm{kg}$ and the drug fluoxetine were given to mice for fourteen days. On the fourteen days after the drug administration tail suspension test and force swim test were performed that showed decrease in an immobility period of mice and plasma corticosterone level and inhibition of monoamine oxidase-A activity, thus responsible for the antidepressant-like activity.

\section{CONCLUSION}

Celastrus paniculatus is a well-known plant in Indian traditional medicine with different medicinal uses and negligible side effects. In this review, we concluded traditional uses, ethnobotanical study, organoleptic characters, chemical constituents and pharmacological uses in a descriptive manner. Best use of seeds of drugs with memory-enhancing activity or as nervine tonic. Other traditional uses are as sedative, tranquilizer, in paralysis, rheumatism, leprosy, bacterial infection and as wound healing agents. Literature review showed that most of the reported activities like anti-arthritic antioxidant, hypo lipidemic, iron chelating, nootropic and cognitive enhancement activity are by different extracts of Celastrus paniculatus seeds which may be due to celapanin, celapagine, celapanigine, $\beta$-amyrin, $\beta$-sitosterol, stigmaserol, malkanguinol, malkangunin and paniculatadiol. Only a few activities are reported with the use of leaves, roots and flower extract. So there is a need to explore the other parts of Celastrus paniculatus also for the beneficial effects as they also contain active constituents like ntriacontanol, pristimerin, benzoic acid, quinine and golden yellow oil, zeylasterol, zeylasterone, celastrol, phenolic triterpenoids and tannins. This review will be useful as the scientific story of Celastrus paniculatus.

\section{FUNDING}

Nil

\section{AUTHORS CONTRIBUTIONS}

All the authors have contributed equally.

\section{CONFLICT OF INTERESTS}

\section{Declared none}

\section{REFERENCES}

1. Tandon V, Gupta RK. Histo-morphological changes induced by Vitex negundo in albino rats. Indian J Pharmacol 2004;36:176-7

2. Bhowmik D, Sampath KKP, Tripathi P, Chiranjiv B. Traditional herbal medicines-an overview. Arch Appl Sci Res 2009;1:165-77.

3. Wealth of India. A dictionary of Indian raw materials and industrial products. $3^{\text {rd }}$ edition. Publication and information directorate council of scientific and industrial research; New Delhi; 1992.

4. Kirtikar KR, Basu BD. Indian medicinal plants. $2^{\text {nd }}$ edition. Lalit Mohan Publication; Allahabad; 1995.

5. Wagner H, Burning R. Chemistry, chemotaxonomy, biosynthesis and pharmacology. Phytochemistry 1978;17: 1821-58.

6. Spivey AC, Weston M, Woodhead S. Celastraceae sesquiterpenids: biologic activity and synthesis. Chem Soc Rev 2002;31:43-59.

7. Nayar MP, Shashtry ARK. Red data book of Indian medicinal plants. Botanical Survey of India: Calcutta; 1987.

8. Tu YQ, Wu TX, Li ZZ, Zhen T, Chen YZ. Sesquiterpene polyol esters from Celastrus paniculatus. Magn Reson Chem 2005;7:650-5.

9. Pavanand K, Webster HK, Nanavati DD. Chemistry and pharmacology of Celastrus paniculatus wild against plasmodium falciparum in vitro. Phytother Res 1989;4:136-9.

10. Sengupta A, Bhargava HN. Chemical investigation of the seed of Celastrus paniculatus. J Sci Food Agric 1970;18:628-31.

11. Denhertog JR, Kruk C, Nanavati DD, Sukh Dev. Stereochemistry of malkanguniol and stereo structures of some other related polyalcohols from Celastrus paniculatus wild. Tetrahedron Lett 1974;26:2219-22.

12. Henry TA. The plant alkaloids. $4^{\text {th }}$ edition. Jand A Churchill Ltd; London; 1949.
13. Ramadan MF. Celastrus paniculatus oil. Fruit oils: Chemistry and functionality. Springer Cham; 2019.

14. Basu NK, Pabrai PR. A chemical investigation of Celastrus paniculatus wild. J Pharm Sci 1946;9:272-3.

15. Gamlath CB, Gunatilaka AAL, Tejuka Y, Kikuchi T, Balasubramaniam S. Qunine-methide, phenolic and related triterpenoids of plants of celastraceae: further evidence for the structure of Celastranhydride. Phytochemistry 1990;10:3189-92.

16. Gattu M, Kenneth LB, Alvin VT, Jerry JB. Reversal of scopolamine-induced deficits in navigational memory performance of the seed oil of Celastrus paniculatus. Pharmacol Biochem Behav 1996;57:793-9.

17. Singh N, Gilca M. Herbal medicine, science embraces tradition-a new insight into the ancient Ayurveda. Germany: Lambert Academic Publishing; 2010. p. 213-26.

18. Deodhar KA, Shinde NW. Celastrus paniculatus: traditional and ethano botanical study. Indian J Plant Res 2015;2:18-21.

19. Singh H, Krishna G, Baske PK. Plants used in the treatment of joint diseases (rheumatism, arthritis, gout, lumbago) in the Mayurbhunj district of Odisha, India. Report Bot Surv India 2010;2:22-6.

20. Wakabayashi N, Wu WJ, Waters RM, Redfern RE. Celagulin: a non-alkaloidal insect and antifeedant from Chinese bittersweet, Celastrus angulatus. J Nat Prod 1988;51:537.

21. Chen PD, Liang JY. The progress of studies on constituents and activities of genus celastrus. Strait Pharm J 1999;11:3.

22. Katchrinnee P, Webster HK, Yongvanitchit K, Kunanke A, Dechatiwongse T, Nutakul W, et al. Schizontocidal activity of Celastrus paniculatus wild. against Plasmodium falciparum in vitro. Phytother Res 1989;1:136-9.

23. Vaidyaratnam PSV. Indian medicinal plants: a Salai. Madras, India; 1997;2:47-51.

24. Agarwal DP. Himalayan medicine system and its materia medica. Himvikas publication; Nainital; 2010.

25. Chopra and Khanna. Conservation of some useful medicinal plants of Hardwar district in Uttaranchal state. Medicinal plants: Conservation and Cultivation; 2007.p. 147-66.

26. Parotta JA. Healing plants of peninsular India. CFBI, New York; 2001.

27. Nath V, Khatri PK. Traditional knowledge on ethno-medicinal uses prevailing in tribal pockets of Chindwara and Betul Districts, MP, India. Afr J Pharm Pharmacol 2010;9:662-70.

28. Mohsen Y. Ethnobotanical study and traditional uses of Celastrus paniculatus. Int I Innov Sci Eng Tech 2015;11:1-5.

29. Jadeja BA, Odera NK, Gajera MR. Plants used in traditional phytotherapy for hair care in Gujarat, India, Jodhpur, Scientific Publications; 2006. p. 258-68.

30. Bhosale SV, Ghule VP, Aundhe DJ, Jagtap SD. Ethanomedical knowledge of plants used by tribal people of Purandhar in Maharashtra, India. Ethanobot Leaflets 2006;13:1353-61.

31. Kamble SY, Patil SR, Sawant PS, Pawar SG, Singh EA. Studies on plants used in traditional medicine by Bhila tribe of Maharashtra. Indian J Trad Knowl 2010;3:591-8.

32. Patil HM, Bhaskar VV. Medicinal uses of plants by tribal medicine men of Nandurbar District in Maharashtra. Nat Prod Rad 2006;2:125-30.

33. Patil RH, Prakash K, Maheshwari VL. Hypolipidemic effect of Celastrus paniculatus on experimentally induced hyper cholesterolemic wistar rats. Indian J Clin Biochem 2010;4:405-10.

34. Karanth KS, Haridas KK, Gunasundari S, Guruswami MN. Effect of Celastrus paniculatus on learning process. J Arogya 1980;6:137-9.

35. Bidwai PP, Wangoo D, Bhullar N. The anti spermatogenic action of Celastrus paniculatus seed extract in the rat with reversible changes in liver. J Ethnopharmacol 1990;3:293-303.

36. Singh M, Verma GN, Srivastava K. An assessment of anti-fertility efficacy of ethanol extract of Celastrus paniculatus seed in male albino rats. J Pharm Biol Sci 2018;4:67-72.

37. Ahmad F, Khan RA, Rasheed S. Preliminary screening of methanolic extracts of Celastrus paniculatus and Tecomella undulata for analgesic and anti-inflammatory activities. J Ethnopharmacol 1994;3:193-8.

38. Parimala S, Shashidhar GH, Sridevi CH, Jyothi V, Suthakaran R Anti-inflammatory activity of Celastrus paniculatus seeds. Int J Pharma Tech Res 2009;4:1326-9. 
39. Kulkarni YA, Agarwal S, Garud MS. Effects of Jyotishmati (Celastrus paniculatus) seeds in animal model of pain and inflammation. J Ayur Integr Med 2015;2:82-8.

40. Gattu M, Pauly JR, Boss KL, Summers JB, Buccafusco JJ. Cognitive impairment in spontaneously hypertensive rats: role of central nicotinic receptors. Brain Res 1997;771:89-103.

41. Bhagya V, Thomas C, Rao BSS. The neuroprotective effect of Celastrus paniculatus on chronic stress-induced cognitive impairment. Indian J Pharmacol 2016;48:687-93.

42. Gupta YK, Kumar MHV. Antioxidant and cognitive property of Celastrus paniculatus wild.-a possible mechanism in enhancing cognition. Phytomedicine 2002;4:302-11.

43. Bhanumathy M, Harish MS, Shivaprasad HN, Sushma G. Nootropic activity of Celastrus paniculatus seed. Pharm Biol 2010;3:324-7.

44. Raut SB, Parekar RR, Jadhav KS, Marathe PA, Rege NN. Effect of Jyotismati seed oil on spatial and fear memory using scopolamine induced amnesia in mice. Anc Sci Life 2015;3:130-3.

45. Jakka AL. A study on nootropic activity of Celastrus paniculatus wild whole plant methanolic extract in rats. Asian J Pharm Clin Res 2016;1:336-41.

46. Alama B, Haque E. Anti-alzheimer and antioxidant activity of Celastrus paniculatus seed. Iranian J Pharm Sci 2011;1:49-56.

47. Sharma P, Shrivastava NM. In vitro evaluation of antioxidant activity of ethanolic leaves extract of Celastrus paniculatus. Int Pharm Sci Res 2013;12:4682-4.

48. Harish BG, Krishna V, Sharath R, Swamy HMK, Naika HR, Mahadevan KM. Antibacterial activity of celapanin, a sesquiterpene isolated from the leaves of Celastrus paniculatus wild. Int J Biomed Pharm Sci 2007;1:65-8.

49. Singh S, Srivastava R, Choudhary S. Antifungal activity and HPLC analysis of crude extracts of Acorus calamus, Tinospora cordifolia and Celastrus paniculatus. J Agric-Tech 2010;1:149-58.

50. Sasidharan ATK, Elyas KK. Anti-fungal potential and brine shrimp lethality assay of in vitro raised clones of Celastrus paniculatus. Asian J Biol Sci 2019;4:877-83.

51. Sumathi TC, Shobana V, Mahalakshmi R, Sureka M, Subathra A, Vishali, et al. Oxidative stress in the brains of male rats intoxicated with aluminium and neuromodulating effect of Celastrus paniculatus alcoholic seed extract. Asian J Pharm Clin Res 2013;6:80-90.

52. Nakhva YJ, Anandpara RC, Sojitra BN, Ganatra TH. Evaluation of iron-chelating potential of methanolic extract of seeds of Celastrus paniculatus on iron intoxicated rats. J Chem Pharm Res 2015;12:1104-12.

53. Kothavade PS, Bulani VD, Deshpande PS, Chowdhury AS, Juvekar AR. The petroleum ether fraction of Celastrus paniculatus Wild. seeds demonstrate the anti-arthritic effect in adjuvant-induced arthritis in rats. J Trad Chin Med Sci 2015;2:183-93.

54. Thangaraj P. In vitro anti-arthritic activity, pharmacological assays of plant-based natural products, Progress in Drug Research, Springer, Cham; 2016. p. 71.

55. Valecha R, Dhingra D. Behavioral and biochemical evidences for the antidepressant-like activity of Celastrus paniculatus seed oil in mice. Basic Clin Neurosci 2016;1:49-56. 